\title{
The Discussion on the Quality Improvement of English Teachers in the Internet+Era
}

\author{
Chunmei Yang \\ Neijiang Normal University, Neijiang Sichuan, 641100, China
}

Keywords: Internet+, English teacher, Quality.

\begin{abstract}
English teachers are the facilitator and performer of English teaching, and the overall quality of education in English class must be related to their abilities. Nowadays, the coming of Internet+ era not only brings the new opportunities to the improvement of English education, but also puts forward the new and higher requirements to the qualities of English teacher. Therefore, we should find ways and means to improve the comprehensive qualities of English teachers constantly by adopting the new methods in the Internet era. This article clarifies the important significance of the quality improvement of English teachers with Internet era, and analyzes the current situation of English teachers' teaching abilities, as well as several ideas about the quality enhancement of English teachers in Internet era.
\end{abstract}

\section{Introduction}

Upon the coming of Internet +era, modern information technology has been increasingly occupied every aspect of modern life, and the network has not only become the important factor and promoting strength to change modern work and study significantly, but also has become the important opportunity to promote the deep reform of English teaching. Faced with new situation and new problems, how to improve the quality of English teachers has aroused great concern from all walks of life in the society. The exploration on the strategy of the quality improvement of English teachers lays great significance on the promotion of English teaching reform and the improvement of English education quality. English education, as the author thinks, should be closely linked to the technology in the information age, such as the cloud computing, big data,etc, and also be applied into the English classroom teaching. Gradually, the comprehensive qualities of English teachers can be enhanced, and more wonderful lectures can be given to the students.

\section{The importance of improving English teachers' qualities in the Internet+ era}

Teachers' qualities have been regarded as the total among teaching knowledge, ability and belief, which is concluded by the strict teacher education, and is based on the good existing characteristics of teachers. Teachers' qualities usually include the ideological and political quality, professional technical quality, psychological quality, etc. As the teaching facilitators, the good qualities of English teacher are not only the important guarantee for the complement of all the teaching tasks and the implement of knowledge convey, but also are the important basis for teachers to do their researching work and the key method to shape their individual important guarantee. After the coming of Internet+ era, teachers should follow the development steps of this age, and improve their own information qualities. Meanwhile, the teaching ideas should be updated, and the new teaching methods should be introduced. The talent English teaching team with strong abilities and high qualities must be constructed and the combination of internet technology and English education must be promoted. What's more, the overall qualities of English education should be improved in essence. 


\section{The analysis on the current teaching abilities of English teachers}

Firstly, the backward teaching methods and ways has greatly influenced the learners' improvement of English competence and performance. Most of English educators are using the traditional intensive teaching method during their teaching,so, the cramming and Duck stuffing teaching measures are used in the class, and make the learners feel boring and dull. Therefore, it will be hard to get rid of educator-center pattern during the teaching, and learners can do nothing but accept what they have been taught during class. Under the long-time influence by this kind of teaching method, learners will have less and less chances to get into the English practice during the English class, so, it will be hard to form the sound overall knowledge structure in their minds. All these will affect the cultivation of learners' language practical abilities, and interfere the development of their creative thinking ability.

Secondly, most teachers' lacking of information application ability affects the cultivation of learners' independent learning ability. Normally, teachers are the knowledge facilitators and initiators, and they are the main bodies during the teaching. Therefore, the communication and interaction between students and them will be lack, which will greatly affect the subjective initiative of learners.

Especially in the Internet+ era, there are a lot of complex teaching resources provided by the internet, while quite a lot of English educators are lack of the abilities of refining resources and applying the information technology.

English teachers are bad at the application of education technology, and it is difficult for them to take the interesting and personalized teaching videos, make the courseware and do the platform interaction, which leads that students are not able to participate in teaching actively. Also, students' potential are hard to get enhanced. Therefore, the comprehensive improvement of their independent learning abilities are influenced greatly.

\section{Several ideas on the strengthen of the English teachers' qualities in Internet+ era}

First, the traditional roles of English educators should be transformed, and teachers' teaching concepts need to be updated continuously.English teachers. In the Internet+ era, English teachers should transform their own traditional roles comprehensively. In the mean time, they should improve and update their teaching concepts in the concrete teaching, and establish the new teaching concepts about learner-center and classroom teaching as main body. The traditional teaching methods and concepts will make learners less motivated. English teachers should update their own English teaching concepts and try their best to introduce the internet into English teaching gradually during their teaching. Moreover, they should apply the new type of teaching methods to the class, so that learners can be motivated, then students will participate in the communication and interaction with teachers more actively. Therefore, learners' enthusiasm to English learning will be promoted and the effectiveness of English teachers' teaching will be raised.

Second, the information quality of English teacher should be improved, and the comprehensive quality of this group must be strengthened. The challenge of Internet+ era brings the information characteristic to the teachers' qualities. In the Internet+ era, the management department should seize the chances of the new round reform on teaching, and improve the investment intensity on modern information technology, and create the relaxing and harmonious information environment. At the same time, Carrying out the hierarchical training on English teachers must be promoted,and a variety of modern information technology training and lectures must be held. Create the network information platform, and continuously promote the construction of high level and high quality English education team. For English teachers, in order to improve their own information qualities, they should be more active in the study of modern network information technology, and apply the modern information technology to update their English professional knowledge. By the way, they should also have the good knowledge of professional teaching cutting-edge knowledge, and integrate the practical English teaching with the modern information technology. In the mean time, teachers should pay more attention to promote their individual working performance by means of modern network educational platform, so that the teaching difficulties that cannot be solved practically in the class can be solved quickly and effectively, which can help them get rid of the heavy and complicate teaching tasks. 
Naturally, the life-long learning concept under the modern information environment can be formed and their life-long learning abilities can be improved as well.

Third, the key to strengthen the construction of teachers' qualities is to improve their information teaching levels. Teaching level is the important component of the modern teachers' professional qualities, which generally includes the teaching theoretical frame level, teaching analysis level and curriculum analysis and development level. Curriculum analysis and development level is one of the comprehensive teacher qualities, and the information teaching level is in it. The information teaching level not only shows the professional level of teachers, but also embodies the comprehensive quality of teachers' group. After the coming of Internet+ era, it seems that there launches a new reform in the traditional teaching methods, which comprehensively covers the former teaching methods and makes them turn to be open from closed form. And now, it pays more attention to the ability rather than the scores. Under the all-around instruction of the education reform, English teachers should make every efforts to be the guiders in the Internet+ era, and turn themselves into the designers and participators of English class teaching activities from their roles as controllers in English class. They should apply the new internet technology to improve their teaching resources on English, and join in the all kinds of teaching competitions, such as Massive Open Online Courses, micro courses and flipping class, so that the creative teaching abilities under the information situation can be improved constantly. Therefore, it will make the information teaching become a normal statue in the English teaching activity.

Fourth, improving the researching abilities of English teachers is also the important part of strengthening the qualities of English teachers. It is an inevitable development tendency that teachers have become the researchers based on the Internet+ conditions. Under this background, schools should pay more attention to the English teaching and researching work. Also, the investment on English teachers' teaching and researching work must be increased. Moreover, schools should provide more rich teaching and researching resources, such as digital library, CNKI, Wanfang, all kinds of education websites, etc, so that English teachers can do the research and promote them to publish papers with high quality and high level topics. Also, schools should improve the scientific research evaluation and incentive system, and create a better researching atmosphere. What's more, schools should promote English teachers to do scientific researches, and and actively create a high quality team. To English teachers, it is necessary to use the teaching research platform and participate in it. For example, use online library resources reasonably, download teaching information research toolkit actively, dedicated to declare a national or provincial, municipal research topic, and join in the online platform for scientific research paper submission. On the same day, English education workers also can use email, micro blog, wechat, and all kinds of technical methods to communication, or do virtual research even cooperation with their peers, so as to enhance their personal abilities of scientific researching and teaching. During the concrete teaching process, English teachers should fully recognize that scientific researching and teaching is the great driving force, and apply the scientific research achievements in English teaching, so as to fully show the huge leading value.of scientific researching and teaching.

Fifth, Cultivate the innovative thinking abilities of English teachers. There is one idea about, that English teaching in Internet + era is to do the English teaching activities in the classroom which is equipped with the modern information technology facilities. Compared to previous English classroom teaching, it only increases some advanced equipment which can show the characteristics of the Internet + era. The proponents of this view actually do not know the Internet+ era. In fact, in nowadays English class, apart from the more advanced facilities, English teachers should also have innovative thinking. Nowadays, some English teachers are very imaginative and creative in their English teaching. For example, some English teachers set up some English columns to publish English articles for students through official accounts in wechat, which is very popular among students. Moreover, English teachers in the school will also share the articles in their moments when they see these articles. As a result, the students will be very proud that their English teachers publish their English articles on the official accounts in wechat, which will improve students' enthusiasms on English writing and their abilities of English writing and reading. Based on the new requirement of 
Internet + era, English teacher will face to more difficult and serious challenges, which not only requires them to have the courage and spirit to study and innovate, but also to be able to apply the Internet technology creatively. Due to the importance of innovation and innovative thinking in current English education, the new requirement in Internet+ era to English teachers is to apply more internet technology into English education in a better way

Sixth, help English teachers set up the user's thinking. At present, the flipped classroom, caused the great response in the educational field, is the concrete manifestation of the user's thinking. And its basic application mode is: transferring the traditional model that teachers give classes and students take classes into a new modal comprehensively, so that students can make full use of time to finish their extracurricular independent learning,whereas the traditional classroom teaching becomes the effective carrier of interaction between teachers and students, which will be mainly used to report, discuss,consult,etc, then the more ideal teaching effect can be achieved. The user's thinking must be based on the users-center when thinking in the most procedures among the value chain. English teachers must understand the true and concrete demands of learners, and changes the teacher-center teaching method practically, and try their best to achieve students-center teaching method. Of course, English teachers must make adjustments to teaching ways and contents according to the learners' real English proficiency and progress at any time. In the past, the average score, gradation rate and excellence rate in English would always be calculated. With the introduction of modern information technology, we can fully grasp the micro performance of every learners with the big data finding technique. Under the condition of having the capacity to apply big data, English educators can control every learners' specific learning processes, and can help students carry on the online FAQ, which makes English teaching more convenient and have more sufficient basis. Because of this, English education workers should establish good users thinking consciousness, and let them be able to carry out the teaching work with quantitative method, then the better teaching effect can be achieved.

\section{Conclusion}

In conclusion, as the coming of "Internet +" era, it brings new chance to the continuous improvement of English education level in our country. Every English educators need to think that how to take advantage of the internet and information on English education reform in a deep way. In the internet+ era, In order to promote their own English education qualities constantly and the process of the English educational reform in China, English teachers should apply the internet technology, and form the life-long learning concepts, and accumulate their individual comprehensive knowledge as well as the information teaching abilities, so that the talents with higher education of high level quality and proficiency in English can be cultivated.

\section{References}

[1] Zhang Qingdong. Discussion on the quality of college English teachers and the way of self-discovery, Education and career, 2011(5).

[2] Cui Yanli. Research on the information teaching ability of university teachers, China education academic journal, 2014(5).

[3] Wang Lili, Yang Fan. Research on college teaching reform and development in the background of Internet era, The research of Heilongjiang university, 2015(8).

[4] Zhang Jing. How can college English teachers deal with campus English in the "Internet +" era, Campus English, 2015(18).

[5] Sun Tai Qun . English classroom teaching and English learning in network environment, The journal Chang Chun normal university, 2006(1). 